\title{
FORECASTING BARLEY YELLOW DWARF VIRUS IN AUTUMN-SOWN CEREALS IN 1998
}

\author{
D.A.J. TEULON, M.A.W. STUFKENS, \\ D. NICOL, and S.J. HARCOURT \\ New Zealand Institute for Crop \& Food Research Ltd, \\ P.O. Box 4704, Christchurch, New Zealand
}

\begin{abstract}
Aphid vectors of barley yellow dwarf virus (BYDV) were sampled from three $7.5 \mathrm{~m}$ high suction traps in Canterbury from April to October 1998. Aphid numbers were very high (up to 193 aphids per trap per week) in April and May and medium to low ( 0 to 44 aphids per trap per week) from June to September. A BYDV forecast based solely on numbers of aphids caught in traps (aphid flights), or primary infestation, accurately predicted high virus incidence for wheat sown before mid-May. However, an exceptionally mild winter encouraging the secondary spread of aphids within crops was implicated in the high level of BYDV found in wheat crops sown after mid-May that was not predicted by aphid flights. A measure of secondary aphid infestation and virus infection may need to be included in future BYDV forecasts. Keywords: aphids, BYDV, autumn wheat, virus forecast, suction trap.
\end{abstract}

\section{INTRODUCTION}

Autumn sown wheat is susceptible to the aphid-transmitted barley yellow dwarf virus (BYDV). This disease has remained one of the major sources of yield loss in cereal crops in New Zealand (Smith and Wright 1964; Close 1969; Stufkens and Farrell 1988; Farrell and Stufkens 1992) since it was discovered in 1953. At least six aphid vectors of BYDV are present in New Zealand (Farrell and Sward 1989; Farrell and Stufkens 1992) with the cereal aphid (Rhopalosiphum padi) (also known as the bird cherry oat aphid) the most common in autumn (Farrell and Stufkens 1992). Unless otherwise stated 'aphid' is used for all aphid vectors of BYDV in cereal crops in this article.

The incidence of BYDV in autumn wheat varies considerably between years and is influenced both by primary and secondary aphid infestation and virus infection. 'Primary' infection is the result of (1) the size and timing of autumn aphid flights, (2) the proportion of aphids in autumn flights that infest crops, and (3) the proportion of infesting aphids that are capable of transmitting BYDV. 'Secondary' infection is the result of (1) the extent of primary infection and, (2) winter and spring weather conditions which affect the survival, development and spread of aphids within crops.

In Canterbury, the main autumn aphid flights occur from March to May (Lowe 1967a; Farrell and Stufkens 1992). To reduce the risk of BYDV in autumn sown crops, farmers have been encouraged to sow crops after mid-May so that susceptible plants emerge after most aphid flights have ceased (Lowe 1967b; Farrell and Stufkens 1992). However, in recent years there has been a trend for crops to be sown earlier (mid-April onwards) to obtain higher yields.

As a result of severe outbreaks of BYDV in 1962, 1985, 1987 and 1990 associated with late aphid flights in June and July, Lowe (1963) and Farrell and Stufkens (1992) proposed forecasting programmes to assess the risk of BYDV to autumn cereals based on the size and timing of autumn aphid flights alone. Farrell and Stufkens (1992) found a significant relationship between aphid numbers caught in a $7.5 \mathrm{~m}$ high suction trap in June and July and the proportion of crops sown after mid-May with economic 
infestations ( $>5 \%)$ of BYDV. This relationship has continued to hold in recent years (Teulon, unpublished data). As a result, BYDV severity in crops sown after mid-May can be predicted in August. This allows for the application of insecticides, if required, before secondary spread and infection commences in spring (Farrell and Stufkens $1988 ; 1989)$. In general primary BYDV infection is rarely severe enough to cause crop loss. Most crop damage results from the secondary spread of virus by aphids from the initial foci (Plumb and Johnstone 1995).

Since 1997, the aphid monitoring-virus forecasting programme has been extended to include three suction traps in Canterbury (Teulon et al. 1998). In the present paper, we describe a year, 1998, of high BYDV incidence in autumn wheat in Canterbury, examine its probable causes and discuss its implications to the aphid monitoring-virus forecasting programme.

\section{Aphid flights}

\section{METHODS}

Aphid flights were monitored with enclosed-cone suction traps (Johnson and Taylor 1955). Traps with $305 \mathrm{~mm}$ diameter aerofoil fans drawing air at approx. $60 \mathrm{~m}^{3} /$ min sucked aphids flying at $7.5 \mathrm{~m}$ through a long metal cylinder (300 $\mathrm{mm}$ dia. x 6.5 $\mathrm{m}$ long) into collecting jars. Traps were situated at Lincoln (Canterbury Agricultural and Science Centre), Hilton (Earl Road, South Canterbury) and Rokeby (Farquhars Road, Mid Canterbury), and were operated from April to October 1998. Traps were emptied weekly and aphids collected, identified and counted.

\section{BYDV levels}

The amount of BYDV in 51 Canterbury autumn- and winter-sown wheat crops (latitude $43^{\circ} 38^{\prime} \mathrm{S}$. to $44^{\circ} 8^{\prime} \mathrm{S}$., altitude 10 to $320 \mathrm{~m}$ above sea level) was estimated between 30 November and 9 December 1998 when all crops were at early flowering growth stages. Crops sown before and after mid-May and with and without insecticide treatment were selected. For each crop, the number of flag leaves with characteristic BYDV symptoms (yellow and/or red colouration; D'Arcy 1995) was counted and the percentage BYDV incidence by area was estimated in about 18 quadrats, each $1 \mathrm{~m}^{2}$. At least six quadrats ( $40 \mathrm{~m}$ apart) were sampled from three transects in each field. Transects were $>40 \mathrm{~m}$ apart and $>20 \mathrm{~m}$ from field margins. Crops which exhibited extensive signs of water stress (brown leaves) were not scored. Information on cultivar, sowing date, and insecticide treatment for the crops was obtained from farmers in August and January.

\section{Virus forecast}

A forecast of likely BYDV incidence was established for autumn crops sown before and after mid-May for all sites in August. This was based on the total number of aphids caught in traps in April and May for early sown crops, and June and July for late sown crops, as well as the historical record of aphid flights and BYDV incidence, and the relationship developed by Farrell and Stufkens (1992).

\section{Aphid flights}

\section{RESULTS AND DISCUSSION}

Aphid flights in 1998 followed the typical bi-modal seasonal pattern usually found in Canterbury (Fig. 1a). However, peak autumn catches were very high at all sites, with over 100 aphids per trap per week caught on several occasions. In 17 years of suction trapping at Lincoln these amounts have seldom been exceeded in autumn (Farrell and Stufkens 1992; D. Teulon unpubl. data).

From April to July inclusive, when autumn sown cereals were at greatest risk from aphid infestation, most species caught in suction traps were R. padi (85-99\%). At Hilton, South Canterbury, the apple grass aphid (R. insertum) was also common $(15 \%)$, but not at other sites (1-4\%). The significance of this aphid is discussed elsewhere (Teulon et al. 1999). Other cereal-infesting aphid species trapped included Metopolophium dirhodum (0-0.2\%) and Sitobion nr. fragariae (0.1-0.6\%). Rhopalosiphum padi was also the most common (97\%) species found in ground suction samples in a selection of the autumn wheats crops (D. Teulon unpubl. data). 

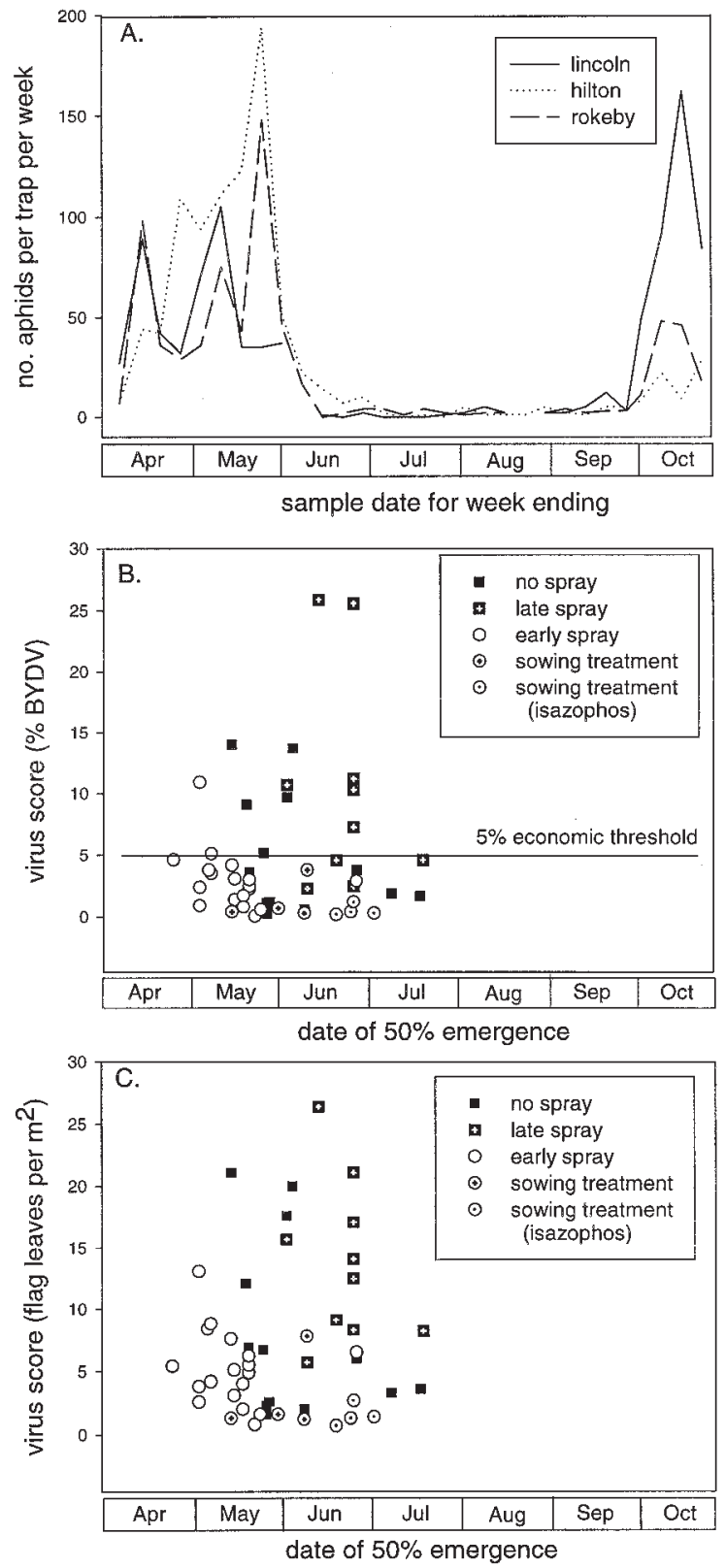

FIGURE 1: Numbers of BYDV aphid vectors in $7.5 \mathrm{~m}$ high suction traps and virus scores for selected Canterbury autumn- and winter-sown wheat crops (1998). A, aphid numbers; $B$, percent virus incidence; $C$, number of virus infected flag leaves per $\mathbf{m}^{2}$. 


\section{Virus levels}

The mean number of flag leaves exhibiting obvious BYDV symptoms and BYDV incidence are plotted against the date of $50 \%$ crop emergence in Figs. $1 \mathrm{~b}$ and c. Crop emergence was estimated to be 150 degree days (base temp. $0^{\circ} \mathrm{C}$, Lincoln temperatures) after sowing date (P. Jamieson, pers comm.).

Mean number of flag leaves showing BYDV symptoms ranged from 0.7 to 26.4 per $\mathrm{m}^{2}$ and BYDV incidence ranged from 0.1 to $25.8 \%$ per $\mathrm{m}^{2}$. The crops with highest virus incidence emerged before 25 June 1998. Most (24 out of 26) early sprayed (in May, June or August), or crops treated at sowing were below the 5\% BYDV level used as a threshold for BYDV severity (Farrell and Stufkens 1992), irrespective of emergence date, although a number of crops were close to the threshold. About half of the unsprayed or late-sprayed crops ( 12 out of 22 ) were below the $5 \%$ threshold but four of these crops were sown very late (after 5 June) and were late emerging (after 26 June), and two of the remaining crops were from Sheffield which had little virus overall. A high proportion (six of 10) of crops sprayed late (in October or November) had $>5 \%$ BYDV incidence. The late sprays were probably effective in reducing aphid numbers but were ineffective for virus control. In general BYDV virus incidence was high to severe in Canterbury in 1998.

\section{Forecast accuracy}

Virus forecasts in 1998 were based solely on the timing and size of aphid flights. Therefore a high, and accurate, BYDV risk was forecast for crops emerging before 1 June. However, medium (Hilton) and low (Lincoln and Rokeby) BYDV risk was forecast for crops emerging after 1 June based on relatively low aphid numbers in suction traps in June and July. This forecast considerably underestimated the amount of virus in these crops, especially for crops sown in late May and emerging in midJune.

Previous BYDV outbreaks in Canterbury have been associated with extensive aphid flights in June and July (i.e., primary infection) and, until now, information from the timing and size of these flights has proved sufficient to predict BYDV outbreaks. However, in 1998 extensive BYDV infection occurred in crops sown after mid-May without large flights in June and July, so other factors that influence BYDV incidence (see above) may need to be considered in future forecasts.

In New Zealand, $R$. padi does not overwinter on trees (Farrell and Stufkens 1992) so it is reasonable to assume that the proportion of aphids in autumn flights colonising cereal crops remains constant from year to year. There has been no attempt to measure yearly differences in the proportion of colonising aphids that are capable of transmitting BYDV in New Zealand, partly because this is not easy to determine.

Winter weather conditions influence the survival, development and spread of aphid colonizers within crops (i.e., secondary infection). The 1998 winter, estimated by the number of degree days (DD) from June 1 to August 31 (base temp. $10^{\circ} \mathrm{C}$ ) at Lincoln, was the mildest recorded since 1980 (31.9 DD for 1998 compared to an average of $16.8 \mathrm{DD}$ for all years). Only three other years in this period had similar values for winter degree days ( 24 to 31 DD) but very small autumn aphid flights from April to July (Farrell and Stufkens 1992). Only seven (1984), six (1988) and nine (1989) aphids were caught in the Lincoln suction trap in June and July in these years compared to 24, 32 and 56 at Lincoln, Rokeby and Hilton, respectively in 1998.

A measure of winter conditions and their influence on aphid secondary spread within cereal crops may need to be included in the BYDV forecasts in future, especially if winter conditions continue to become more favourable for aphids.

\section{ACKNOWLEDGEMENTS}

We thank the following farmers for their help: Tony Whatman, Jim McCartney, John Butcher, John Honeywell, Tony Pannett, Graeme Robertson, Rob McDowell, Roger Slater, Ken Pierce, Stuart Wright and Terry Johnstone. We are indebted to Stuart Sheat (Hilton) and John and Mathew Honeywell (Rokeby) for emptying the suction traps and to Damien Coup for sorting suction trap catches. This project was financially supported by the Agricultural Market and Research Development Trust 
(Progressive Farming Grant), the Foundation for Arable Research and the Foundation for Research, Science and Technology.

\section{REFERENCES}

Close, R., 1969. Summary of trials for the control of barley yellow dwarf virus. Proc. 22nd N.Z. Weed and Pest Cont. Conf:: 214-216.

D’Arcy, C.J., 1995. Symptomology and host range of barley yellow dwarf. Pp. 9-28. In: Barley Yellow Dwarf 40 Years of Progress. C.J. D'Arcy and P.A. Burnett (Eds.). APS Press, St Paul, Minnesota.

Farrell, J.A. and Stufkens, M.W., 1988. Abundance of the rose-grain aphid, Metapolophium dirhodum, on barley in Canterbury, New Zealand. N.Z. J. Zool. 15: 499-505.

Farrell, J.A. and Stufkens, M.W., 1989. Flight activity and cereal host relationships of Rhopalosiphum spp. in Canterbury. N.Z. J. Crop and Hort. Sci. 17: 1-7.

Farrell, J.A. and Stufkens, M.W., 1992. Cereal aphid flights and barley yellow dwarf virus infection of cereals in Canterbury, New Zealand. N.Z. J. Crop and Hort. Sci. 20: 407-412.

Farrell, J.A. and Sward, R.J., 1989. Barley yellow dwarf virus serotypes and their vectors in Canterbury, New Zealand. Aust. Plant Pathol. 18: 21-23.

Johnson, C.G. and Taylor, L.R., 1955. The development of large suction traps for airborne insects. Ann. Appl. Biol. 43: 51-62.

Lowe, A.D., 1963. Warning services on aphid flights. Proc. 16th N.Z. Weed Control Conf: : 108-109.

Lowe, A.D., 1967a. Sowing date as an aphid-virus control technique. Proc. 20th N.Z. Weed and Pest Control Conf:: 214-216.

Lowe, A.D., 1967b. Avoid yellow dwarf by late sowing. N.Z. Wheat Review 10: 59-63.

Plumb, R.T and Johnstone, G.R., 1995. Cultural, chemical, and biological methods for the control of barley yellow dwarf. Pp. 307-319. In: Barley Yellow Dwarf 40 Years of Progress. C.J. D'Arcy and P.A. Burnett (Eds.). APS Press, St Paul, Minnesota.

Smith, H.C. and Wright, G.M., 1964. Barley yellow dwarf virus on wheat in New Zealand. N.Z. Wheat Review 9: 60-79.

Stufkens, M.W. and Farrell, J.A., 1988. Effects of cereal host, insecticide and locality on the incidence of barley yellow dwarf virus in the South Island. Proc. $41^{s t}$ N.Z. Weed and Pest Control Conf.: 34-38.

Teulon, D.A.J. and Stufkens, M.A.W., 1998. Forecasting barley yellow dwarf virus in Canterbury winter sown cereals. Proc. $51^{\text {st }}$ N.Z. Plant Prot. Conf:: 263.

Teulon, D.A.J., Nicol, D. and Stufkens, M.A.W., 1999. Apple grass aphid (Rhopalosiphum insertum) on cereals in Canterbury. Proc. $52^{\text {nd }}$ N.Z. Plant Prot. Conf.: (this volume). 